\title{
Catalyzed Trisodium Citrate as a Medium for Heavy Metals Treatment in Green-Lipped Mussels (Perna viridis)
}

\author{
Ihsan Wan Azelee*, Razali Ismail", Wan Azelee Wan Abu Bakar, Rusmidah Ali, \\ Rugayah Mohamed, Nurul Asma Samsudin, Hashim Baharin \\ Department of Chemistry, Faculty of Science, Universiti Teknologi Malaysia, Johor, Malaysia \\ Email: ${ }^{*}$ zali@kimia.fs.utm.my, ${ }^{*}$ ihsanwanazelee@gmail.com
}

Received March 15, 2013; revised April 17, 2013, accepted May 10, 2013

Copyright (C) 2013 Ihsan Wan Azelee et al. This is an open access article distributed under the Creative Commons Attribution License, which permits unrestricted use, distribution, and reproduction in any medium, provided the original work is properly cited.

\begin{abstract}
This research was carried out to study the heavy metals removal like arsenic (As), lead $(\mathrm{Pb})$, cadmium $(\mathrm{Cd})$, nickel $(\mathrm{Ni})$ and mercury (Hg) from Perna viridis. The trisodium citrate with $\mathrm{Ru} / \mathrm{Mn}(25: 75)-\mathrm{Al}_{2} \mathrm{O}_{3}$ catalyst were used for the treatment medium with optimum treatment conditions at $500 \mu \mathrm{g} / \mathrm{g}$ of dosage, at temperature of $35^{\circ} \mathrm{C} \pm 1{ }^{\circ} \mathrm{C}$, at $\mathrm{pH} 7$, for 5 hours of duration and in the presence of compressed air (flow rate $895.50 \mathrm{~mL} / \mathrm{min}$ ). The introduction of $\mathrm{Ru} / \mathrm{Mn}$ (25:75) $-\mathrm{Al}_{2} \mathrm{O}_{3}$ catalyst at $100^{\circ} \mathrm{C}$ calcination temperature on the trisodium citrate medium indicates the reduction of heavy metals which achieved the permissible limit by Malaysian Food Regulations (1985) and Commission Regulation of EU (2006). The original concentrations of As: $1.65 \pm 0.89 \mu \mathrm{g} / \mathrm{g}, \mathrm{Hg}: 12.42 \pm 0.53 \mu \mathrm{g} / \mathrm{g}, \mathrm{Pb}: 6.25 \pm 0.69 \mu \mathrm{g} / \mathrm{g}, \mathrm{Cd}$ : $1.27 \pm 0.25 \mu \mathrm{g} / \mathrm{g}$ and Ni: $2.00 \pm 1.05 \mu \mathrm{g} / \mathrm{g}$ were reduced to As: $0.75 \pm 0.04 \mu \mathrm{g} / \mathrm{g}(54.34 \%), \mathrm{Hg}: 0.4 \pm 0.02 \mu \mathrm{g} / \mathrm{g}$ (96.79\%), Pb: $1.07 \pm 0.02 \mu \mathrm{g} / \mathrm{g}$ (82.89\%), Cd: $0.32 \pm 0.10 \mu \mathrm{g} / \mathrm{g}(75.02 \%)$ and Ni: $0.76 \pm 0.01 \mu \mathrm{g} / \mathrm{g}(61.83 \%)$. ICP-MS and MHS-AAS techniques were used for the metals analysis and the catalyst was characterized through X-ray Diffraction (XRD), Field Emission Scanning Electron Microscopy (FESEM) and Energy Dispersive X-Ray (EDX) and Nitrogen Absorption (NA).
\end{abstract}

Keywords: Perna viridis; Heavy Metal; Trisodium Citrate; Catalyst

\section{Introduction}

The green-lipped mussel, Perna viridis (Family: Mytilidae) is a local seafood delicacy. This bivalve is a filter feeder which feeds on phytoplankton, small zooplankton and other organic materials. This natural habitat may accumulate heavy metals over the years which enter the water and food cycles through a variety of chemical and geochemical processes [1-5]. Even low heavy metals content will possess toxic effect for human when intake is excessive [6].

Chelating agent is capable of forming a complex ring-like structure when comes in contact with a metal ion [7]. Studies have reported the application of chelating agents on heavy metals removal from human by deferasirox in chelation therapy, deferroxamine (DFO) and deferiprone (DFP) on fish, potassium butyl dithiophosphate (PBD) on wastewater, 1,3-benzenediamidoethanethiolate $\left(\mathrm{BDET}^{2-}\right)$ on groundwater, citric acid on solid waste, oxalic and acetic acid on soil and sodium citrate

"Corresponding authors. on sediment [8-14]. Upon the catalyst application, studies have shown the enhancement toward the removal of polycyclic hydrocarbons (PAHs) in waste incinerator, the production of hydrogen from the supercritical water gasification (SCWG) and naphthenic acid removal in the acid solution model chemical reaction [15-17].

Biomonitoring the Perna viridis species have increased the awareness for health effect toward heavy metals contimination. Even though depuration process had been carried out to naturally purify transition metal contamination from the bivalves, only removed small amount of heavy metals while requires long time for process such as $\mathrm{Hg}(23.3 \%)$ in 20 days and $\mathrm{Zn}(40 \%), \mathrm{Pb}$ $(18.5 \%)$ and $\mathrm{Cu}(63.3 \%)$ in 24 days [18]. Hence, no commercially viable industrial technology was currently developed for the removal of the toxic elements. The purpose of the study is to remove heavy metals (As, $\mathrm{Hg}$, $\mathrm{Pb}, \mathrm{Cd}$ and $\mathrm{Ni}$ ) from contaminated Perna viridis using trisoidum citrate with the addition of $\mathrm{Ru} / \mathrm{Mn}$ (25:75)$\mathrm{Al}_{2} \mathrm{O}_{3}$ catalyst. The result should compliment with the permissible limit set by the Malaysian Food Regulations (1985) and Commission Regulation of EU (2006). 


\section{Materials and Methods}

\subsection{Apparatus}

$\mathrm{As}, \mathrm{Pb}, \mathrm{Cd}$ and $\mathrm{Ni}$ metals were analyzed through Inductive Coupled Plasma Mass Spectrometry, ICP-MS (Perkin Elmer ELAN 6100) while Hg determination was done by Mercury-Hydride Atomic Absorption Spectrometer, MHS-AAS (Perkin Elmer AAnalyst 400). The prepared catalyst was characterized using Nitrogen Absorption (Quantachrome Autosorb-1), Field Emission Scanning Electron Microscopy, X-ray Diffraction (Bruker AXS D8 Automatic Powder Diffractometer), and Energy Dispersive X-Ray (JEOL JSM-6701F). A pH meter (Hanna Instrument) was used to verify the $\mathrm{pH}$ of the citrate salt to achieve the desired $\mathrm{pH}$.

\subsection{Materials}

All reagents used in the study were analytical grade and were used without any purification. All the solutions were prepared using deionized water obtained from the NANO pure water system. Samples were digested using $\mathrm{HNO}_{3}$ (Sigma Adrich, 65\%). All the plastic and glassware were cleaned by soaking in diluted $\mathrm{HNO}_{3}(10 \%)$ and rinsed with distilled water prior to use. The element standard solutions used for calibration were produced by diluting a stock solution of 29 elements standard 3 (10 $\mathrm{mg} / \mathrm{L}$ ) supplied by Merck, Germany. The chelating agent used was trisodium citrate dihydrate, $\mathrm{C}_{6} \mathrm{H}_{5} \mathrm{Na}_{3} \mathrm{O}_{7} \cdot 2 \mathrm{H}_{2} \mathrm{O}$ (Sigma Adrich) while for the catalyst, the chemicals were Manganese (II) chloride (MERCK Eurolab), Ruthenium (III) chloride (MERCK Eurolab) and Aluminium Oxide (Sigma Adrich).

\subsection{Catalyst Preparation}

The catalyst was prepared by dissolved $\mathrm{RuCl}_{3}$ and $\mathrm{MnCl}_{2} \cdot 2 \mathrm{H}_{2} \mathrm{O}$ with $25: 75$ ratios in triply distilled water (2 $\mathrm{mL}$ ). Then $\mathrm{Al}_{2} \mathrm{O}_{3}$ beds were 3 times impregnated in the catalyst solution for 15 minutes each. The catalyst was then washed with triply distilled water until no color changing of $\mathrm{AgNO}_{3}$ reagent. Later, it was aged at $80^{\circ} \mathrm{C}$ for 24 hours before further calcined at $1000^{\circ} \mathrm{C}$ for another 5 hours. All analysis was done in three series of replicates and the Perna viridis was rinsed with deionized water before the metals analysis.

\subsection{Sampling}

Perna viridis of average sizes of $9.0 \mathrm{~cm}-11.5 \mathrm{~cm}$ and sea water samples were collected from each 4 sampling site along Pantai Lido-Pendas coastal area (Figure 1) from October 2010 to March 2011. These mussel samples were brought back to the laboratory and were stored at $-10^{\circ} \mathrm{C}$ until treatment while the sea water samples were preserved with $65 \% \mathrm{HNO}_{3}(5 \mathrm{~mL} / \mathrm{L})$ for metal analysis.

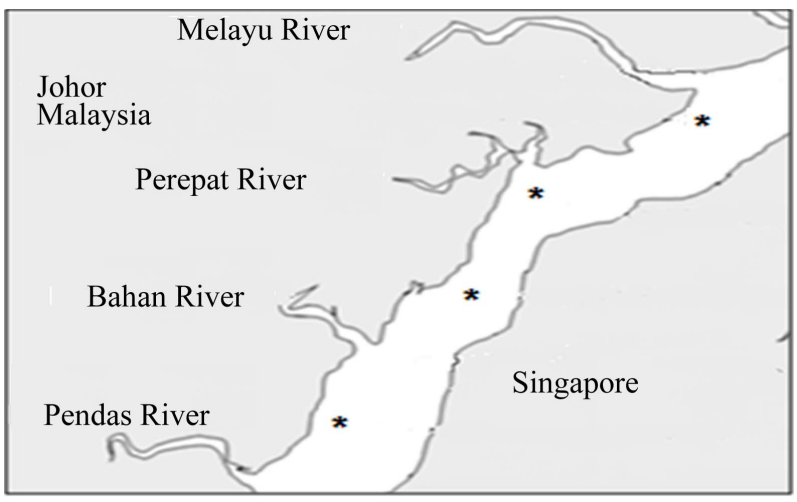

Figure 1. The sampling location from Pantai Lido-Pendas coastal area marked by $(*)$.

\subsection{Heavy Metals Removal}

Treatment for the heavy metals removal in Perna viridis was conducted using trisodium citrate in the presence of $\mathrm{Ru} / \mathrm{Mn}(25: 75)-\mathrm{Al}_{2} \mathrm{O}_{3}$ catalyst. The samples were put in sack and were soaked in the beaker $(250 \mathrm{~mL})$ that contains the chelating agents with stirring for 5 hour under the optimum treatment condition at $500 \mu \mathrm{g} / \mathrm{g}$ of dosage, at temperature of $35^{\circ} \mathrm{C} \pm 1{ }^{\circ} \mathrm{C}$, at $\mathrm{pH} 6-7$, for 5 hours of duration and in the presence of compressed air (flow rate $895.50 \mathrm{~mL} / \mathrm{min}$ ).

\subsection{Metal Analysis}

All prepared samples were digested using $65 \%$ of $\mathrm{HNO}_{3}$ (APHA $3030 \mathrm{E}$ ). The digestion was done through partial reflux until clear solutions were obtained. After the digestion process, the samples were allowed to cool and filtered through a Whatman Grade 2 filter Paper and then diluted to $50 \mathrm{~mL}$ with deionized water. The prepared samples were then analysed for $\mathrm{As}, \mathrm{Pb}, \mathrm{Cd}$ and $\mathrm{Ni}$ using ICP-MS while MHS-AAS for $\mathrm{Hg}$. The concentrations are presented in $\mu \mathrm{g} / \mathrm{g}$. To check for contamination and performance of the instrument, procedural blank and standard were analysed once for every ten samples.

\section{Results}

\subsection{Heavy Metal Concentrations in Perna viridis}

The initial concentrations of heavy metals $(\mu \mathrm{g} / \mathrm{g})$ in the Perna viridis from 4 sampling points are presented in Table 1.5 batches of sampling were done from October 2010 to March 2011. For this study, the average of initial concentration for 5 samples (represent 5 sampling times) was used to calculate the percentage of heavy metals removed after the treatment. From Table 1, the averages of the studied heavy metals were above and exceed the permissible limit by Malaysian Food Regulations (1985) and Commission Regulation of EU (2006). 
Table 1. Initial heavy metals concentration in Perna viridis with the permissible limit stated by Malaysia and EU.

\begin{tabular}{|c|c|c|c|c|c|}
\hline Sampling time & As $(\mu \mathrm{g} / \mathrm{g})$ & $\mathrm{Hg}(\mu \mathrm{g} / \mathrm{g})$ & $\mathrm{Pb}(\mu \mathrm{g} / \mathrm{g})$ & $\mathrm{Cd}(\mu \mathrm{g} / \mathrm{g})$ & $\mathrm{Ni}(\mu \mathrm{g} / \mathrm{g})$ \\
\hline October 2010 & $0.84 \pm 0.24$ & $10.20 \pm 0.31$ & $0.70 \pm 0.27$ & $0.28 \pm 0.11$ & $1.03 \pm 0.03$ \\
\hline November 2010 & $1.88 \pm 0.58$ & $24.42 \pm 0.17$ & $9.81 \pm 0.55$ & $1.78 \pm 0.15$ & $2.00 \pm 0.07$ \\
\hline December 2010 & $2.04 \pm 0.11$ & $7.48 \pm 0.36$ & $5.44 \pm 0.23$ & $2.21 \pm 0.08$ & $3.59 \pm 0.81$ \\
\hline January 2011 & $1.75 \pm 0.62$ & $9.00 \pm 0.12$ & $8.52 \pm 0.18$ & $0.51 \pm 0.13$ & $1.44 \pm 0.62$ \\
\hline February 2011 & $1.70 \pm 0.03$ & $11.02 \pm 0.09$ & $6.80 \pm 0.12$ & $1.57 \pm 0.07$ & $1.97 \pm 0.25$ \\
\hline Average initial concentration & $1.65 \pm 0.89$ & $12.42 \pm 0.53$ & $6.25 \pm 0.69$ & $1.27 \pm 0.25$ & $2.00 \pm 1.05$ \\
\hline Permissible limit, & $\mathrm{Mal}$ & \multicolumn{4}{|c|}{ As, Cd and Ni $(1.00 \mu \mathrm{g} / \mathrm{g}) ; \mathrm{Pb}(2.00 \mu \mathrm{g} / \mathrm{g}) ; \mathrm{Hg}(0.50 \mu \mathrm{g} / \mathrm{g})$} \\
\hline
\end{tabular}

\subsection{Catalytic Treatment}

The preliminary study on the catalytic treatment was done to identify the effect of $\mathrm{Ru} / \mathrm{Mn}(25: 75)-\mathrm{Al}_{2} \mathrm{O}_{3}$ catalyst towards metals chelation of trisodium citrate. The heavy metals concentration with and without the presence of catalyst were determined. The results are illustrated in Figure 2. The result showed that with the presence of $\mathrm{Ru} / \mathrm{Mn}$ (25:75) $-\mathrm{Al}_{2} \mathrm{O}_{3}$ catalyst, the percentage removal of the heavy metals increases up to $20 \%$ compared to none $\mathrm{Ru} / \mathrm{Mn}(25: 75)-\mathrm{Al}_{2} \mathrm{O}_{3}$ catalyst in trisodium citrate medium. Hence, the catalyst was optimized to get the optimum catalytic activity.

\subsection{Optimization of Catalyst}

The calcination temperature of $\mathrm{Ru} / \mathrm{Mn}(25: 75)-\mathrm{Al}_{2} \mathrm{O}_{3}$ catalyst were varied at $900^{\circ} \mathrm{C}, 1000^{\circ} \mathrm{C}$ and $1100^{\circ} \mathrm{C}$ for 5 hours. The catalytic treatment activities are summarized in Figure 3. The result shows that calcination temperatures for $1000^{\circ} \mathrm{C}$ gave higher catalytic activity for the catalyst on $\mathrm{As}, \mathrm{Pb}$ and $\mathrm{Hg}$ when compared with calcination temperature at $900^{\circ} \mathrm{C}$ and $1100^{\circ} \mathrm{C}$. Whereby, $\mathrm{Cd}$ and $\mathrm{Ni}$ followed the order $900^{\circ} \mathrm{C}>1000^{\circ} \mathrm{C}>1100^{\circ} \mathrm{C}$ and $1100^{\circ} \mathrm{C}>$ $1000^{\circ} \mathrm{C}>900^{\circ} \mathrm{C}$ respectively. The percentage removal achieved at $1000^{\circ} \mathrm{C}$ was As: $62.66 \%, \mathrm{~Pb}: 85.19 \%, \mathrm{Cd}$ : $77.10 \%$, Ni: $60.20 \%$ and Hg: $96.96 \%$.

The optimization for the loading of the catalyst, $\mathrm{Ru} / \mathrm{Mn}$ (25:75) $-\mathrm{Al}_{2} \mathrm{O}_{3}$ was varied by $1: 1$ (2.5 g catalyst in 250 $\mathrm{mL}$ sodium citrate) and 1:0.5 (1.25 g catalyst in $250 \mathrm{~mL}$ sodium citrate) ratios. The ratio used was based on volume of citrate salt to the weight of the catalyst. The result is illustrated in Figure 4.

Figure 4 clearly shows that the presence of catalyst even in a small quantity may enhance the removal rate of the heavy metal in Perna viridis. From the result, the dosage of the catalyst at $1.25 \mathrm{~g}$ was selected as both dosage of $\mathrm{Ru} / \mathrm{Mn}(25: 75)-\mathrm{Al}_{2} \mathrm{O}_{3}$ in trisodium citrate did not gave much different in percentage removal of the heavy metals and only differed below $10 \%$.

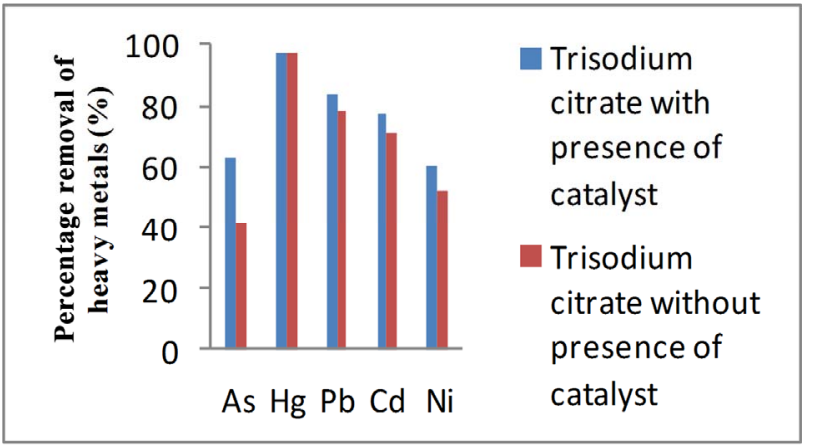

Figure 2. Percentage removal of heavy metals in Perna viridis in the presence of $\mathrm{Ru} / \mathrm{Mn}(25: 75)-\mathrm{Al}_{2} \mathrm{O}_{3}$ catalyst at $900^{\circ} \mathrm{C}$ calcination temperature in trisodium citrate $(500 \mu \mathrm{L} / \mathrm{L})$ medium with $\mathrm{pH} 7$, at $35^{\circ} \mathrm{C} \pm 1^{\circ} \mathrm{C}$ and for 5 hours.

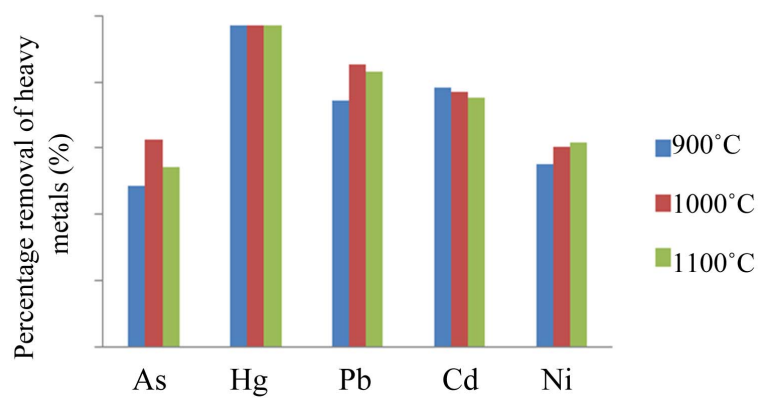

Figure 3. Percentage removal of heavy metals removal for catalyzed trisodium citrate with $\mathrm{Ru} / \mathrm{Mn}(25-75)-\mathrm{Al}_{2} \mathrm{O}_{3}$ catalyst (1.25 g) at various calcination temperatures for 5 hours.

\section{Characterization of Potential Catalyst}

In this study, the characterization techniques of potential catalysts used were carried out by Nitrogen Absorption (NA), Electron Microscopy (FESEM), X-Ray Diffraction Analysis (XRD) and Field Emission Scanning Energy Dispersion X-Ray (EDX).

\subsection{NA}

The surface area and pore diameter of $\mathrm{Ru} / \mathrm{Mn}(25: 75)$ - 
$\mathrm{Al}_{2} \mathrm{O}_{3}$ catalyst were presented in Table 2. The results followed the order of $1000^{\circ} \mathrm{C}>1100^{\circ} \mathrm{C}>900^{\circ} \mathrm{C}$ of calcination temperature.

At $1000^{\circ} \mathrm{C}$, the catalyst achieved the highest surface area $\left(9.576 \mathrm{~m}^{2} \cdot \mathrm{g}^{-1}\right)$ and highest average pore diameter $(84.887 \mathrm{~nm})$ compared to other calcination temperature. In general, bigger pore size creates bigger surface area of the catalyst, hence giving more active sites. However, higher calcination temperature leads to sintering effect and cause migration of particles size to grain in which the particles size increases and surface area decreases while low calcination temperature was unable to create high pore size on the surface of the catalyst which lead to low surface area. Even though the $\mathrm{N}_{2}$ adsorption-desorption isotherms analysis recognized that the catalyst to be Type IV and mesopores at all temperature, but the hysteresis loop as shown in Figure 5 indicates the narrower pore size of the catalyst at $1000^{\circ} \mathrm{C}$ calcinations temperature.

It was proven as it gave higher uptake of nitrogen at high relative pressure and formation of the hysteresis loop at high relative pressure compared to calcination temperature at $900^{\circ} \mathrm{C}$ and $1100^{\circ} \mathrm{C}$. Thus, high catalytic activity achieved at $1000^{\circ} \mathrm{C}$ calcination temperature was due to the higher surface area with bigger and narrower pore size.

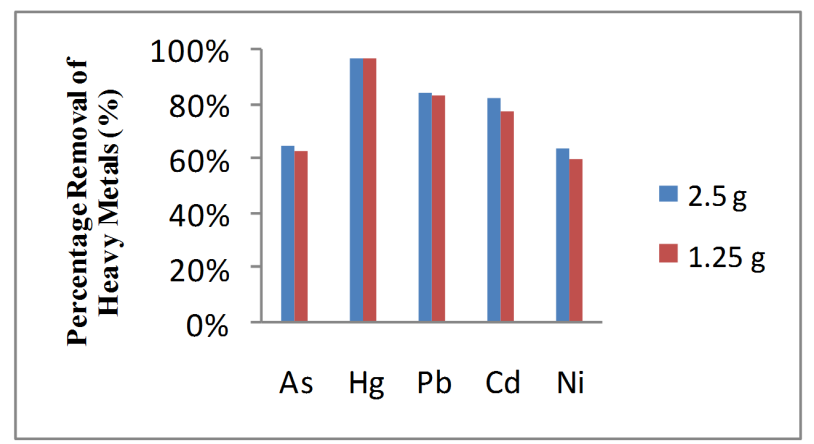

Figure 4. The percentage removal of heavy metals for different dosage of $\mathrm{Ru} / \mathrm{Mn}(25: 75)-\mathrm{Al}_{2} \mathrm{O}_{3}$ catalyst calcined at $1000^{\circ} \mathrm{C}$ in the trisodium citrate $(500 \mu \mathrm{L} / \mathrm{L})$ at neutral $\mathrm{pH}$ (pH 6 - 7), temperature of $30^{\circ} \mathrm{C}-35^{\circ} \mathrm{C}$ with stirring for 5 hours.

Table 2. Surface area $\left(\mathrm{S}_{\mathrm{BET}}\right)$ and $\mathrm{BJH}$ desorption average pore diameter, d (nm) of $\mathrm{Ru} / \mathrm{Mn}(25: 75)-\mathrm{Al}_{2} \mathrm{O}$ catalysts calcined at $900^{\circ} \mathrm{C}, 1000^{\circ} \mathrm{C}$ and $1100^{\circ} \mathrm{C}$ for 5 hours.

\begin{tabular}{ccc}
\hline Calcination Temperature $\left({ }^{\circ} \mathbf{C}\right)$ & $\mathbf{S}_{\text {BET }}\left(\mathbf{m}^{2} \cdot \mathbf{g}^{-1}\right)$ & $\mathbf{D}(\mathbf{n m})$ \\
\hline 900 & 7.369 & 64.160 \\
1000 & 9.576 & 84.887 \\
1100 & 8.454 & 67.993 \\
\hline
\end{tabular}

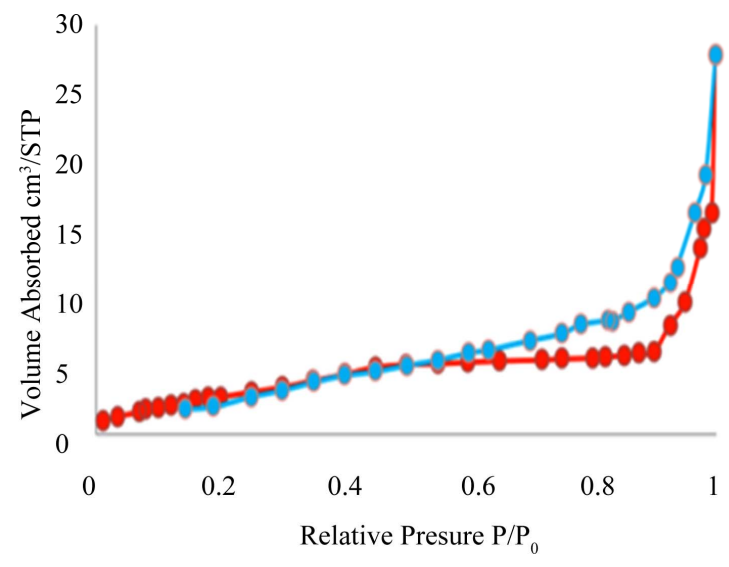

(a)

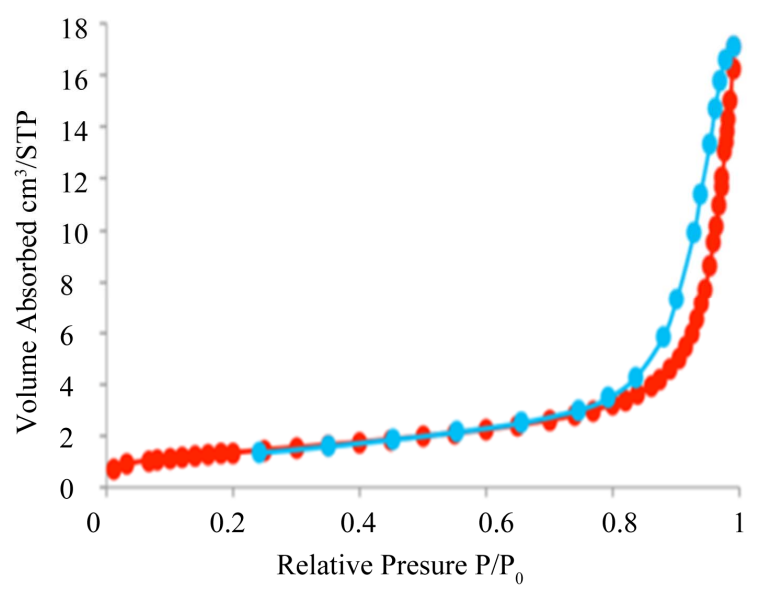

(b)

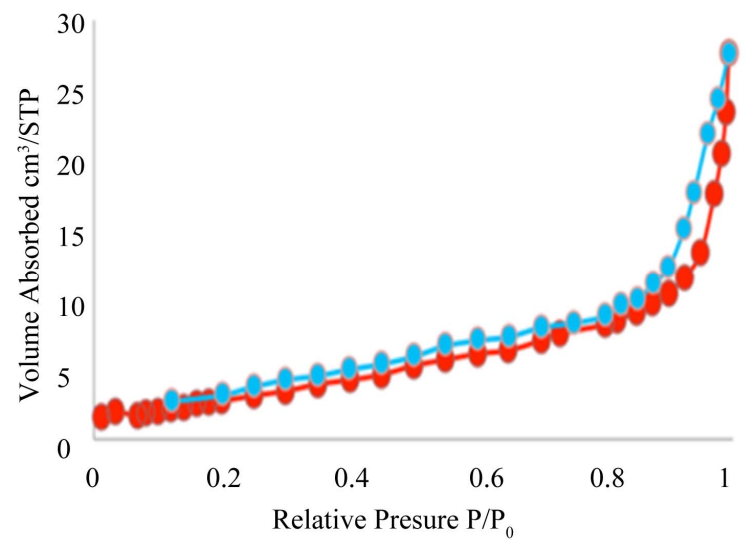

(c)

Figure 5. Isotherm plots of $\mathrm{Ru} / \mathrm{Mn}(25: 75)-\mathrm{Al}_{2} \mathrm{O}_{3}$ catalyst calcined at (a) $900^{\circ} \mathrm{C}$ (b) $1000^{\circ} \mathrm{C}$ and (c) $1100^{\circ} \mathrm{C}$ for 5 hours.

\subsection{XRD}

Figure 6 shows the XRD pattern of Ru/Mn (25:75)$\mathrm{Al}_{2} \mathrm{O}_{3}$ catalyst. All calcination temperature showed the presence of $\mathrm{Al}_{2} \mathrm{O}_{3}$ support in rhombohedral phase with $\mathrm{RuO}_{2}$ tetragonal phase and $\mathrm{Mn}_{2} \mathrm{O}_{3}$ hexagonal phase as the active site species. At $900^{\circ} \mathrm{C}, \mathrm{Al}_{2} \mathrm{O}_{3}$ (rhombohedral) 


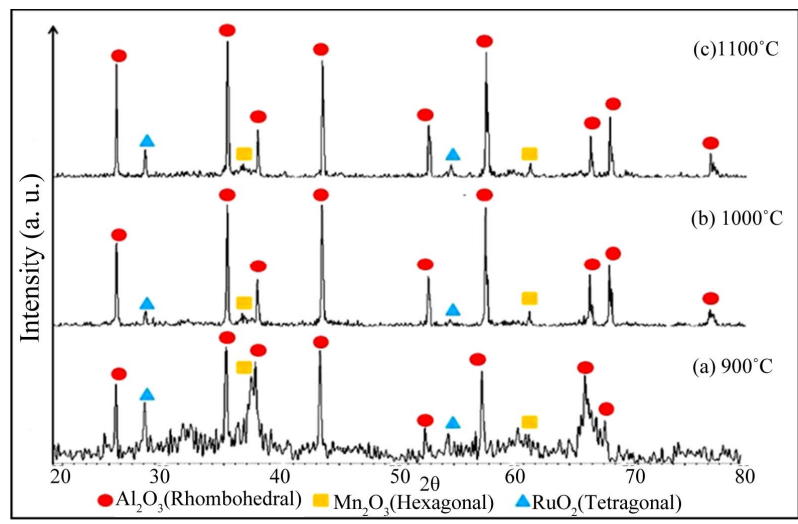

Figure 6. XRD Diffractograms of $\mathrm{Ru} / \mathrm{Mn}(25: 75)-\mathrm{Al}_{2} \mathrm{O}_{3}$ catalysts calcined at (a) $900^{\circ} \mathrm{C}\left(\right.$ b) $1000^{\circ} \mathrm{C}$ (b) and (c) $1100^{\circ} \mathrm{C}$ for 5 hours.

was revealed at $2 \theta=35.131^{\circ}\left(\mathrm{I}_{100}\right), 43.329^{\circ}\left(\mathrm{I}_{96}\right), 57.410^{\circ}$ $\left(\mathrm{I}_{91}\right), 25.550^{\circ}\left(\mathrm{I}_{68}\right), 68.089\left(\mathrm{I}_{52}\right), 52.475(\mathrm{I} 47), 37.323^{\circ}\left(\mathrm{I}_{46}\right)$ and $66.398\left(\mathrm{I}_{35}\right) ; \mathrm{RuO}_{2}$ (tetragonal) at $2 \theta=28.076^{\circ}\left(\mathrm{I}_{100}\right)$ and $54.965^{\circ}\left(\mathrm{I}_{39}\right)$ while $\mathrm{Mn}_{2} \mathrm{O}_{3}$ (hexagonal) at $2 \theta=$ $36.466^{\circ}\left(\mathrm{I}_{100}\right)$ and $61.872^{\circ}\left(\mathrm{I}_{39}\right)$. For $1000^{\circ} \mathrm{C}, \mathrm{Al}_{2} \mathrm{O}_{3}$ (rhombohedral) was found at $2 \theta$ values of $35.126^{\circ}\left(\mathrm{I}_{100}\right)$, $42.323^{\circ}\left(\mathrm{I}_{96}\right), 57.462^{\circ}\left(\mathrm{I}_{91}\right) 25.548^{\circ}\left(\mathrm{I}_{68}\right), 68.217\left(\mathrm{I}_{52}\right)$, $52.519\left(\mathrm{I}_{47}\right), 37.776\left(\mathrm{I}_{46}\right), 66.483\left(\mathrm{I}_{35}\right)$ and $76.869\left(\mathrm{I}_{15}\right)$; $\mathrm{RuO}_{2}$ (tetragonal) at $2 \theta=28.076^{\circ}\left(\mathrm{I}_{100}\right)$ and $54.454^{\circ}\left(\mathrm{I}_{39}\right)$ while $\mathrm{Mn}_{2} \mathrm{O}_{3}$ (hexagonal) at $2 \theta=36.316^{\circ}\left(\mathrm{I}_{100}\right)$ and $61.211^{\circ}\left(\mathrm{I}_{50}\right)$. Whereby, at $1100^{\circ} \mathrm{C}, \mathrm{Al}_{2} \mathrm{O}_{3}$ (rhombohedral) was determined at $2 \theta=35.162^{\circ}\left(\mathrm{I}_{100}\right), 43.350^{\circ}\left(\mathrm{I}_{96}\right)$, $57.514^{\circ}\left(\mathrm{I}_{91}\right) 25.574^{\circ}\left(\mathrm{I}_{68}\right), 68.187\left(\mathrm{I}_{52}\right), 52.5459\left(\mathrm{I}_{47}\right)$, $37.780\left(\mathrm{I}_{46}\right), 66.493\left(\mathrm{I}_{35}\right)$ and $76.901\left(\mathrm{I}_{15}\right) ; \mathrm{RuO}_{2}$ (tetragonal) at $2 \theta=28.041^{\circ}\left(\mathrm{I}_{100}\right)$ and $54.966^{\circ}\left(\mathrm{I}_{39}\right)$ while $\mathrm{Mn}_{2} \mathrm{O}_{3}$ (hexagonal) at $2 \theta=36.451^{\circ}\left(\mathrm{I}_{100}\right)$ and $61.921^{\circ}\left(\mathrm{I}_{50}\right)$.

The result revealed the amorphous state for the catalyst at $900^{\circ} \mathrm{C}$ compared to crystalline state at $1000^{\circ} \mathrm{C}$ and $1100^{\circ} \mathrm{C}$. The high peak intensity of $\mathrm{RuO}_{2}$ tetragonal at $1100^{\circ} \mathrm{C}$ compared to $1000^{\circ} \mathrm{C}$ calcination temperature will increased the crystallinity and may also decreased the surface area as indicated by NA analysis. Therefore, high catalytic activity at $1000^{\circ} \mathrm{C}$ calcination temperature was mainly due the presence of crystalline phase at high surface area.

\subsection{FESEM}

The morphology of $\mathrm{Ru} / \mathrm{Mn}(25: 75)-\mathrm{Al}_{2} \mathrm{O}_{3}$ catalysts were shown by FESEM micrographs in Figure 7. All the images show the formation of aggregation and agglomeration. Through FESEM mapping pattern in Figure 8, both $\mathrm{Ru}$ and $\mathrm{Al}$ species were identified to be in cluster pattern at $900^{\circ} \mathrm{C}$ calcinations temperature while only $\mathrm{Ru}$ species was clustered for $1000^{\circ} \mathrm{C}$ and $1100^{\circ} \mathrm{C}$ calcinations temperature.

High catalytic activity for the catalyst at $1000^{\circ} \mathrm{C}$ calcinations temperature was determined to be inhomogeneous nano particle sizes which vary from $41.4 \mathrm{~nm}$ to

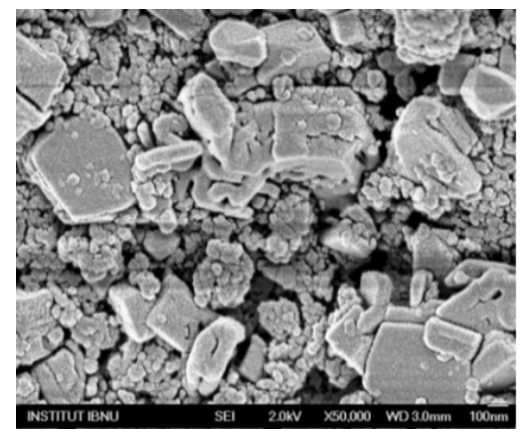

(a)

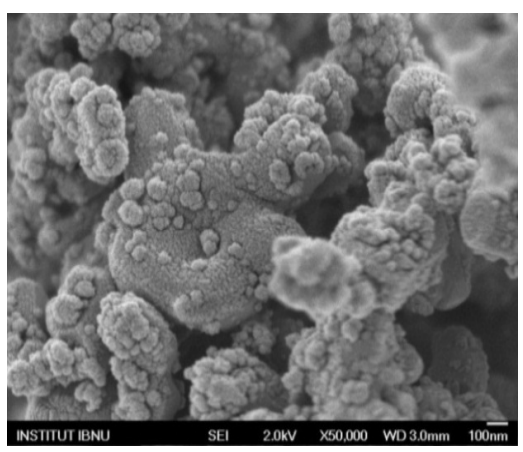

(b)

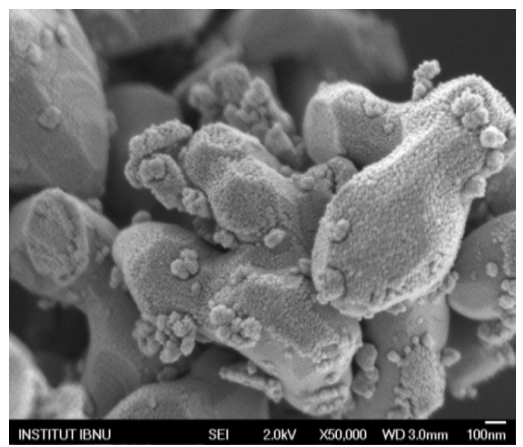

(c)

Figure 7. FESEM micrographs of $\mathrm{Ru} / \mathrm{Mn}(25: 75)-\mathrm{Al}_{2} \mathrm{O}_{3}$ catalyst calcined at (a) $900^{\circ} \mathrm{C}$, (b) $1000^{\circ} \mathrm{C}$ and (c) $1100^{\circ} \mathrm{C}$ for 5 hours (Magnification: 50,000 $\times$, Scale bar: $1 \mathrm{~cm}=100 \mathrm{~nm}$ ).

$85.1 \mathrm{~nm}$. Besides, the particles were shown to project out from the catalyst surface with high aggregation and was parallel with $\mathrm{Ru}$ mapping profile which shown to be more clustered at $1000^{\circ} \mathrm{C}$ compared to $1100^{\circ} \mathrm{C}$. This morphology will increase the surface area of the catalyst and it was in agreement with the result obtained through NA analysis. Whereby, the surface area was lower at $900^{\circ} \mathrm{C}$ as the particles with large number of square shape and uniform small spherical at diameter varies from 74.5 $\mathrm{nm}$ to $122.0 \mathrm{~nm}$ were more flatten on the catalyst surface. Meanwhile at $1100^{\circ} \mathrm{C}$, a capsule like shape and inhomogeneous small spherical shape with diameter sizes varied from $34.4 \mathrm{~nm}$ to $103.6 \mathrm{~nm}$ were presented. The particles were projected out from the catalyst surface but tend to more agglomerated which also lower the surface area. 

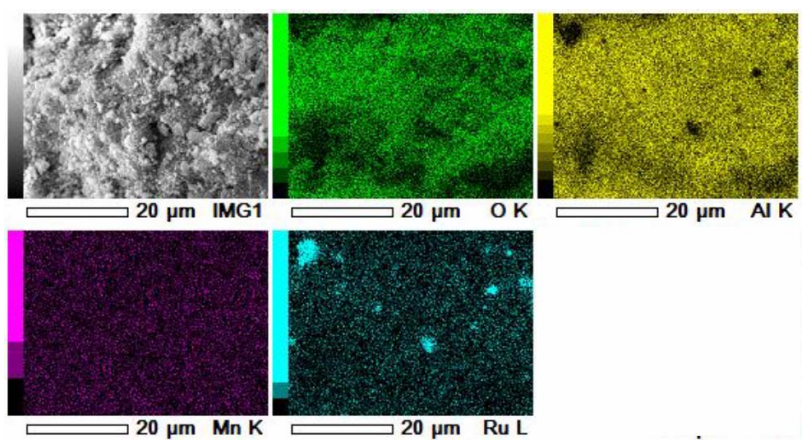

(a)
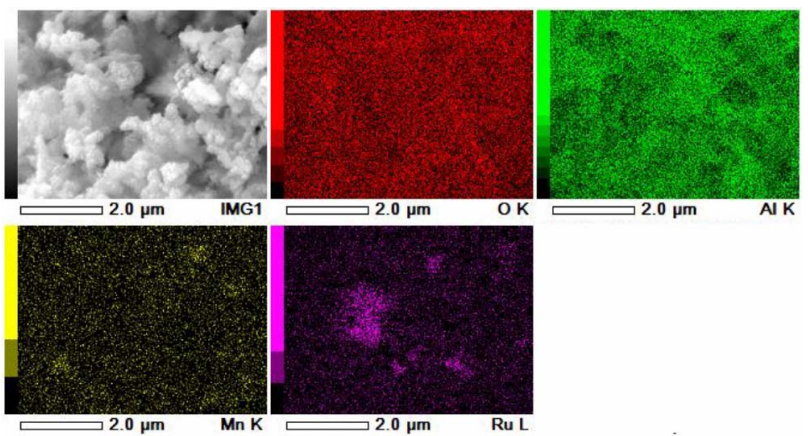

(b)
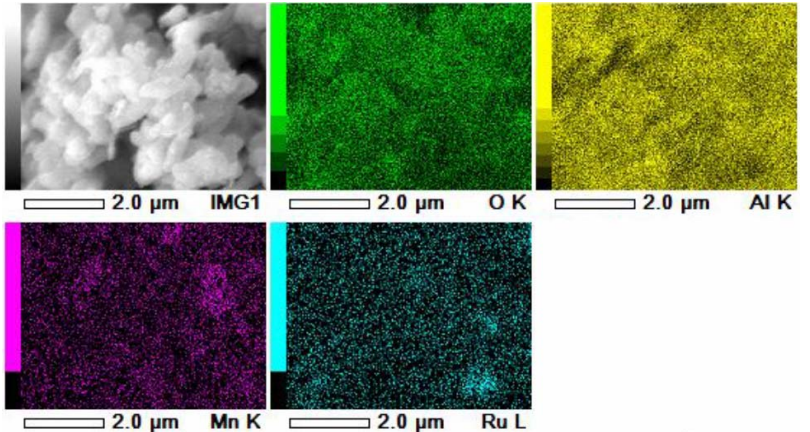

(c)

Figure 8. FESEM Mapping pattern for Ru/Mn (25:75)$\mathrm{Al}_{2} \mathrm{O}_{3}$ catalyst calcined at (a) $900^{\circ} \mathrm{C}$ (b) $1000^{\circ} \mathrm{C}$ and (c) $1100^{\circ} \mathrm{C}$ for 5 hours. (Magnification: 20,000x, Scale bar: 1 $\mathrm{cm}=2.0 \mu \mathrm{m})$.

\subsection{EDX}

The elements composition of $\mathrm{Ru} / \mathrm{Mn}$ (25:75) $-\mathrm{Al}_{2} \mathrm{O}_{3}$ catalyst was shown in Table 3. The result showed the presence of $\mathrm{Al}, \mathrm{O}, \mathrm{Mn}$ and $\mathrm{Ru}$ elements on the catalyst at all studied calcination temperature. $\mathrm{Al}$ and $\mathrm{O}$ elements were attributed to the presence of $\mathrm{Al}_{2} \mathrm{O}_{3}$ as the catalyst support while both $\mathrm{Mn}$ and $\mathrm{Ru}$ elements exhibited as the active species of the catalyst which appeared as individual phases as $\mathrm{Mn}_{2} \mathrm{O}_{3}$ and $\mathrm{RuO}_{2}$ respectively as determined in XRD analysis. The percentage weight of $\mathrm{Mn}$ in the catalyst shows inversely proportional to the calcination temperature while the percentage weight of $\mathrm{Ru}$ in the catalyst followed the order of $1000^{\circ} \mathrm{C}>900^{\circ} \mathrm{C}>1100^{\circ} \mathrm{C}$ of calcination temperature. Thus, indicates the high $\mathrm{Ru}$ aggregation formation as shown in the $\mathrm{Ru}$ mapping profile in FESEM analysis. High percentage of $\mathrm{Mn}$ at $900^{\circ} \mathrm{C}$ on the catalyst not affected the catalytic activity as it act only as a base for $\mathrm{Ru}$ active species on the $\mathrm{Al}_{2} \mathrm{O}_{3}$ support.

\section{Proposed Mechanisms of the Catalytic Activity}

The catalytic activity can be explained with the postulated reaction mechanism shown in Figure 9.

The reaction begins when trisodium citrate solution was been adsorbed on the surface of $\mathrm{Ru} / \mathrm{Mn}$ (25:75)$\mathrm{Al}_{2} \mathrm{O}_{3}$ catalyst (1). Then, the bonding between sodium, hydrogen and oxygen in the compound will be dissociated to form anion and cation (2). At the transition state, citrate ion will bond to the metal ion from the mussel while the sodium ion will bond with $\mathrm{OH}^{-}$from water molecule (3). Later, the production of metal citrate compound and $\mathrm{NaOH}$ will be released into the solution leaving the catalyst alone (4). The catalyst will then proceed their catalytic activity with adsorbing new trisodium citrate compound on their surface. Thus, a cyclic catalytic chelation proceeds again.

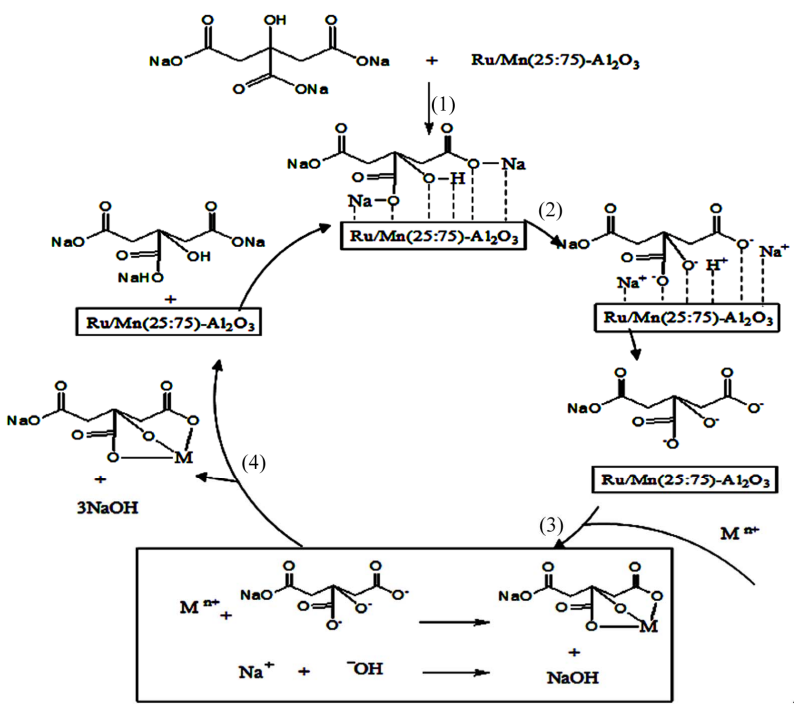

Figure 9. Proposed catalytic chelation cycle for the removal of metal ion from Perna viridis.

Table 3. EDX analysis of $\mathrm{Ru} / \mathrm{Mn}(25: 75)-\mathrm{Al}_{2} \mathrm{O}_{3}$ catalyst calcined at $900^{\circ} \mathrm{C}, 1000^{\circ} \mathrm{C}$ and $1100^{\circ} \mathrm{C}$ for 5 hours.

\begin{tabular}{ccccc}
\hline \multirow{2}{*}{$\begin{array}{c}\text { Calcination } \\
\text { Temperature }\left({ }^{\circ} \mathbf{C}\right)\end{array}$} & Al & O & Mn & Ru \\
\cline { 2 - 5 } & 53.42 & 31.94 & 11.06 & 3.58 \\
900 & 48.31 & 38.45 & 9.09 & 4.15 \\
1000 & 53.15 & 37.74 & 7.60 & 1.51 \\
\hline
\end{tabular}




\section{Conclusion}

The obtained results proved that the catalytic treatment gave higher percentage removal of heavy metals in Perna viridis compared to treatment using only chelating agent. The $\mathrm{Ru} / \mathrm{Mn}(25: 75)-\mathrm{Al}_{2} \mathrm{O}_{3}$ catalyst calcined at $1000^{\circ} \mathrm{C}$, was found to be the best catalyst to enhance the removal of heavy metals in Perna viridis. This catalyst possesses crystalline phase, surface area of $9.576 \mathrm{~m}^{2} \cdot \mathrm{g}^{-1}$ with average pore diameter of $84.887 \mathrm{~nm}$, the isotherm of Type IV with hysteresis loop indicating the presence of mesopores, nano particle sizes which vary from $41.4 \mathrm{~nm}$ to $85.1 \mathrm{~nm}$ and high percentage composition of $\mathrm{Ru}$ and $\mathrm{Mn}$ on the catalyst with $4.15 \%$ and $9.09 \%$ respectively. Furthermore, the presence of $\mathrm{RuO}_{2}$ aggregation species on the catalyst surface suggested as active sites of the catalyst.

\section{Acknowledgements}

We thank Universiti Teknologi Malaysia for the financial support through Research University Grant (Vot No. 02J34).

\section{REFERENCES}

[1] A. M. G. M. Alam, A. Tanaka, G. Allinson, L. J. B. Laurenson, F. Stagnitti and E. Snow, "A Comparison of Trace Element Concentrations in Cultured and Wild Carp (Cyprinus carpio) of lake Kasumigaura, Japan," Ecotoxicology and Environmental Safety, Vol. 53, No. 3, 2002, pp. 348-354. doi:10.1016/S0147-6513(02)00012-X

[2] A. Altındag and S. Yigit, "Assessment of Heavy Metal Concentrations in the Food Web of Lake Beyşehir, Turkey," Chemosphere, Vol. 60, No. 4, 2005, pp. 552-566. doi:10.1016/j.chemosphere.2005.01.009

[3] M. Camusso, R. Balestrini and A. Binelli, "Use of Zebra Mussel (Dreissena polymorpha) to Assess Trace Metal Contamination in the Largest Italian Subalpine Lakes," Chemosphere, Vol. 44, No. 2, 2001, pp. 263-270. doi:10.1016/S0045-6535(00)00169-7

[4] A. Farkas, J. Salanki, and A. Specziar, "Age and SizeSpecific Patterns of Heavy Metals in the Organs of Freshwater Fish Abramis brama L. Populating a Low-Contaminated Site," Water Research, Vol. 37, No. 5, 2003, pp. 959-964. doi:10.1016/S0043-1354(02)00447-5

[5] C. Gundacker, "Comparison of Heavy Metal Bioaccumulation in Freshwater Mollusks of Urban River Habitats in Vienna," Environmental Pollution, Vol. 110, No. 1, 2000, pp. 61-71. doi:10.1016/S0269-7491(99)00286-9

[6] O. D. Uluozlu, M. Tuzen, D. Mendil and M. Soylak, "Trace Metal Content in Nine Species of Fish from the Black and Aegean Seas, Turkey," Food Chemistry, Vol. 104, No. 2, 2007, pp. 835-840. doi:10.1016/j.foodchem.2007.01.003

[7] S. J. S. Flora and V. Pachauri, "Chelation in Metal Intoxication," International Journal of Environmental Re- search and Public Health, Vol. 7, No. 7, 2010, pp. 27452788. doi:10.3390/ijerph7072745

[8] M. Schmid, "Iron Chelation Therapy in MDS: What Have We Learnt Recently?" Blood Reviews, Vol. 23, Suppl. 1, 2009, pp. S21-S25. doi:10.1016/S0268-960X(09)70006-2

[9] S. Sivakumar, C. P. Khatiwada and J. Sivasubramanian, "Bioaccumulations of Aluminum and the Effects of Chelating Agents on Different Organs of Cirrhinus Mrigala," Environmental Toxicology and Pharmacology, Vol. 34, No. 3, 2012, pp. 791-800. doi:10.1016/j.etap.2012.09.007

[10] Y. Xu, Z. Xie and L. Xue, "Chelation of heavy metals by potassium Butyl Dithiophosphate," Journal of Environmental Sciences, Vol. 23, No. 5, 2011, pp. 778-783.

[11] L. Y. Blue, M. A. V. Aelstyn, M. Matlock and D. A. Atwood, "Low-Level Mercury Removal from Ground-Water Using a Synthetic Chelating Ligand," Water Research, Vol. 42, No. 8-9, 2008, pp. 2025-2028. doi:10.1016/j.watres.2007.12.010

[12] K. Huang, K. Inoue, H. Harada, H. Kawakita and K. Ohto, "Leaching of Heavy Metals by Citric Acid From Fly Ash Generated in Municipal Waste Incineration Plants," Journal of Material Cycles and Waste Management, Vol. 13, No.2, 2011, pp. 118-126. doi:10.1007/s10163-011-0001-5

[13] S. Oustan, S. Heidari, M. R. Neyshabouri, A. Reyhanitabar and A. Bybordi, "Removal of Heavy Metals from a Contaminated Calcareous Soil Using Oxalic and Acetic Acids as Chelating Agents," International Conference on Environment Science and Engineering (IPCBEE), Singapore, 16-18 September 2011, pp. 152-155.

[14] J. A. Lucey, L. L. Vintro, D. Boust, P. I. Mitchell, A. Gouzy and L. Bowden, "A Novel Approach to the Sequential Extraction of Plutonium from Oxic and Anoxic Sediment Using Sodium Citrate to Inhibit Post-Extraction Resorption," Journal of Environmental Radioactivity, Vol. 93, No. 2, 2007, pp. 63-73. doi:10.1016/i.jenvrad.2006.11.004

[15] F. Y. Chang, J. C. Chen and M. Y. Wey, "The Activity of $\mathrm{Rh} / \mathrm{Al}_{2} \mathrm{O}_{3}$ and $\mathrm{Rh}-\mathrm{Na} / \mathrm{Al}_{2} \mathrm{O}_{3}$ Catalysts for PAHs Removal in the Waste Incineration Processes: Effects of Particulates, Heavy Metals, and Acid Gases," Fuel, Vol. 88, No. 9, 2009, pp. 1563-1571. doi:10.1016/j.fuel.2009.04.009

[16] S. Li, Y. Lu, L. Guo and X. Zhang, "Hydrogen Production by Biomass Gasification in Supercritical Water with Bimetallic Ni-M $/ \alpha \mathrm{Al}_{2} \mathrm{O}_{3}$ Catalysts $(\mathrm{M}=\mathrm{Cu}$, Co and $\mathrm{Sn})$," International Journal of Hydrogen Energy, Vol. 36, No. 22, 2011, pp. 14391-14400. doi:10.1016/i.ijhydene.2011.07.144

[17] H. Y. Oh, J. H. Park, Y. W. Rhee and J. N. Kim, "Decarboxylation of Naphthenic Acid Using Alkaline Earth Metal Oxide," Journal of Industrial and Engineering Chemistry, Vol. 17, No. 4, 2011, pp. 788-793. doi:10.1016/j.jiec.2011.05.024

[18] P. T. Lakshmanan and P. N. K. Nambisan, "Bioaccumulation and Depuration of Some Trace Metals in the Mussel, Perna viridis (Linnaeus)," Bulletin of Environmental Contamination and Toxicology, Vol. 43, No. 1, 1989, pp. 131-138. doi:10.1007/BF01702249 